\title{
PREHEATED FLY-ASH CATALYZED ALDOL CONDENSATION: EFFICIENT SYNTHESIS OF CHALCONES AND ANTIMICROBIAL ACTIVITIES OF SOME 3-THIENYL CHALCONES
}

\author{
RANGANATHAN ARULKUMARAN ${ }^{\prime}$, SAMBANDHAMOORTHY VIJAYAKUMAR ${ }^{\prime}$, S PAZHANIVEL \\ SAKTHINATHAN ${ }^{1}$, DAKSHNAMOORTHY KAMALAKKANNAN ${ }^{1}$, KALIYAPERUMAL RANGANATHAN", \\ RAMAMOORTHY SURESH ${ }^{1}$, RAJASEKARAN SUNDARARAJAN ${ }^{l}$ GANESAN VANANGAMUDI ${ }^{l}$ AND \\ GANESAMOORTHY THIRUNARAYANAN²*
}

\author{
${ }^{1}$ Postgraduate and Research Department of Chemistry, Government Arts College, C-Mutlur, Chidambaram-608102, India. \\ ${ }^{2}$ Department of Chemistry, Annamalai University, Annamalainagar-608002, India.
}

(Received: June 28, 2012 - Accepted: January 22, 2013)

\begin{abstract}
In the present study we have prepared a series of some chalcones using solvent - free Aldol - condensation by microwave irradiation. The yields of the ketones are more than $60 \%$. The synthesised chalcones were characterized by their analytical, physical and spectral data. The antimicrobial activities of substituted styryl 3-thienyl ketones have been studied using Bauer-Kirby method.
\end{abstract}

Key words: Styryl 3-thienyl ketones, Preheated fly-ash, Crossed-aldol reaction, Solvent free synthesis, Antimicrobial activities

\section{INTRODUCTION}

There are numerous greener and solvent-free ${ }^{1,2}$ synthetic methods available for synthesis of organic compounds. The reactions involving the formation of carbon-carbon bond and carbon-heteroatom bond are important and interesting in green synthesis. Based on this the $\mathrm{Aldol}^{3}$, Crossed-aldol ${ }^{4}$, Knoevenagel ${ }^{5}$, Mannich $^{6}$, Michael $^{7}$ and Wittig ${ }^{8}$ reactions have been applied for synthesising isomeric biologically active compounds such as chalcones and alkenes. Thermal condensation reactions have been found to be sluggish and time-consuming with poor yields. However in the microwave conditions, the reaction is faster, giving appreciable yield involving easier process of isolation of the products. Scientists and specially chemists have used microwave irradiation technique for solid phase green synthesis ${ }^{8,9}$. Numerous green catalysts such as fly-ash: sulphuric acid $^{1}$, silica-sulphuric acid ${ }^{10,11}$ anhydrous zinc chloride ${ }^{12}$, ground chemistry catalysts-grinding the reactants with sodium hydroxide ${ }^{13}$, aqueous alkali in lower temperature ${ }^{14}$, solid sulphonic acid from bamboo ${ }^{15}$, barium hydroxide ${ }^{16}$ anhydrous sodium bicarbonate ${ }^{17}$, microwave assisted synthesis ${ }^{18}$, Fly-ash:water ${ }^{2,19}$, triphenylphosphite ${ }^{20}$, alkali earth metals ${ }^{21}, \mathrm{KF} / \mathrm{Al}_{2} \mathrm{O}_{3}{ }^{22}$ and sulfated titania ${ }^{23}$ and silicotungstic acid ${ }^{24}$ have been reported for the synthesis of many number of organic compounds. Chalcones possess various multipronged activities such as antimicrobial ${ }^{25}$, antidepressant ${ }^{26}$, antiplasmodial ${ }^{27}$, anti-aids ${ }^{28}$ and insect antifeedant activities ${ }^{3,29}$. In the present investigation, the authors wish to report a new green catalyst preheated fly-ash for efficient synthesizing chalcones by Crossed-Aldol condensation reaction. The yields of chalcones are more than $60 \%$. The synthesized chalcones are characterized by their physical constants, Mass, IR and NMR spectral data as they are unknown compounds so far. The purities of the known synthesized chalcones have been checked by their physical constants and their spectral data earlier published in literature. The antimicrobial activities of these chalcones have been studied using BauerKirby method.

\section{EXPERIMENTAL}

\section{Materials and Methods}

All chemicals used were purchased from Sigma-Aldrich and E-Merck chemical companies. Fly-ash was collected from the Thermal Power Plant II, Neyveli Lignite Corporation, Tamilnadu, India. Melting points of all chalcones were determined in open glass capillaries on Mettler FP51 melting point apparatus and are uncorrected. Infrared spectra $\left(\mathrm{KBr}, 4000-400 \mathrm{~cm}^{-1}\right)$ were recorded on AVATAR-300 Fourier transform spectrophotometer. The NMR spectra of chalcones have been recorded in INSTRUM AV300 spectrometer, operating at $500 \mathrm{MHz}$ for ${ }^{1} \mathrm{H}$ and $125.46 \mathrm{MHz}$ for ${ }^{13} \mathrm{C}$ spectra in DMSO solvent using TMS as internal standard. Mass spectra were recorded on a SIMADZU GC-MS2010 Spectrometer using Electron Impact (EI) techniques.

Preparation of preheated fly-ash

'The fly-ash was heated on hot air oven at $110^{\circ} \mathrm{C}$ for $2 \mathrm{~h}$. During the heating demoisturising takes place. This preheating helps for avoiding colloidal formation during the reaction.

General procedure for synthesis of chalcones

Appropriate mixture of aryl methyl ketone $(2 \mathrm{mmol})$ substituted benzaldehydes $(2 \mathrm{mmol})$ and preheated fly-ash $(0.5 \mathrm{~g})$ taken in $50 \mathrm{ml}$ corning glass tube and tightly capped. The reaction mixture was subjected to microwave irradiation for 8-10 minutes at $460 \mathrm{~W}, 2450 \mathrm{~Hz}$, in a microwave oven (Scheme 1) (LG Grill, Intellowave, Microwave Oven, $160-800 \mathrm{~W}$ ) and then cooled to room temperature. Added $10 \mathrm{ml}$ of dichloromethane, the organic layer has been separated which on evaporation yields the solid product. The solid, on recrystallization with benzene-hexane mixture gives glittering pale yellow solid.

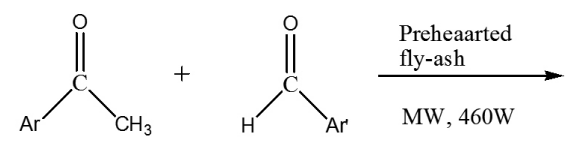<smiles>NC(=O)C=CBr</smiles>

$1-40$

Scheme 1: Synthesis of chalcones using preheated fly-ash catalyzed aldol condensation between aryl methyl ketones and aryl aldehydes.

\section{RESULTS AND DISCUSSION}

Fly ash is a waste air-pollutant and it has many chemical species 1, 2, 20,31 $\mathrm{SiO}_{2}, \mathrm{Fe}_{2} \mathrm{O}_{3}, \mathrm{Al}_{2} \mathrm{O}_{3}, \mathrm{CaO}, \mathrm{MgO}$ and insoluble residues. The waste Fly-ash is converted into preheated fly-ash by heating this in an hot air oven for $2 \mathrm{~h}$ at $110^{\circ} \mathrm{C}$ and it is used as useful catalyst as preheated fly-ash. The above said chemical residues such as $\mathrm{SiO}_{2}, \mathrm{Fe}_{2} \mathrm{O}_{3}, \mathrm{Al}_{2} \mathrm{O}_{3}, \mathrm{CaO}, \mathrm{MgO}$ species present in the fly-ash have enhanced the catalytic activity. During the course of the reactions these species are responsible for the promoting effects on condensation between the aryl ketone and aryl aldehydic groups leading to the formation of unsaturated ketone. The proposed general reaction mechanism is shown in Figure. 1. For this condensation, generally a base is a preferred catalyst. In the case of base catalyzed aldol condensation, generally the mechanism involves the formation of anion of ketone. While in our case preheated fly-ash acts as a solid catalyst, it assists for condensation between enol form of ketone and aldehyde. This catalyst also assists the dehydration of the aldol condensed product then to form chalcones. A similar mechanism has been proposed for this condensation with other catalyst ${ }^{24}$. Further we have investigated this reaction with $2 \mathrm{mmol}(0.25 \mathrm{~g})$ of 3 -acetylthiophene and benzaldehyde $(0.21 \mathrm{~g})$ with in the same condition, the observed yield is $67 \%$. The effect of catalyst loading was studied with this reaction (32, Scheme 2 ) by varying the catalyst quantity from 0.1 to $1 \mathrm{~g}$. As the catalyst quantity is increased from 0.2 to 0.5 $\mathrm{g}$, the percentage of yield of product is increased from 64 to $67 \%$. Further increase the catalyst amount there is no significant increasing of the percentage of product. This catalytic effect is shown in Figure 2. The optimum quantity of 
catalyst loading was found to be $0.4 \mathrm{~g}$. We have carried out this reaction with various substituted ketones and benzaldehydes. The results, analytical and mass spectral data are summarized in Table 1. The Uv, IR and NMR spectroscopic data of the chalcones (entries 32-40) are presented in Table $\mathbf{2}$ and $\mathbf{3}$. There is no significant effect observed for the effects of substituents on the condensation reaction. The reusability of this catalyst was studied the reaction of 3-thienyl ketone and benzaldehyde. The reusability of catalyst on crossed-aldol reaction of 3-thienyl ketone and benzaldehydes was not observed. Because the second run of this reaction did not give more than $60 \%$ of yield and the observed yield is $25-27 \%$ only. There was appreciable loss in its effect of catalytic activity was observed in the second run. In this protocol the reaction gave good yields of the chalcones during the condensation without any environmental discharge.<smiles>C=C([AlH2])O[18OH]</smiles><smiles>C=C([18F])O[18O]C=O</smiles>

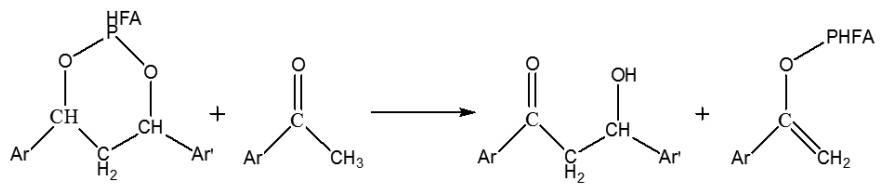

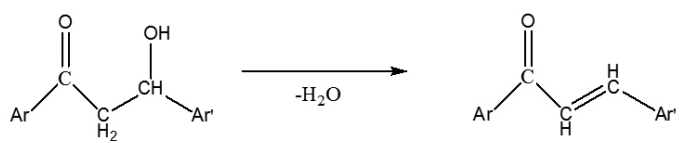

Figure 1: The proposed mechanism for the preheated fly-ash catalyzed aldol condensation between aryl methyl ketone and aryl aldehydes.<smiles>CC(=O)c1ccsc1</smiles><smiles>[X]c1cccc(OC)c1</smiles><smiles>[X]c1ccccc1C#CC(=O)c1ccsc1</smiles>

$\mathrm{X}=\mathrm{H}, 3-\mathrm{Br}, 4-\mathrm{Br}, 4-\mathrm{Cl}, 4-\mathrm{F}, 2-\mathrm{OCH}_{3}, 4-\mathrm{CH}_{3}, 3-\mathrm{NO}_{2}, 4-\mathrm{NO}_{2}$

Scheme 2: Synthesis of substituted styryl 3-thienyl ketones using preheated fly-ash catalyzed aldol condensation between 3-acetylthiophene and substituted benzaldehydes.

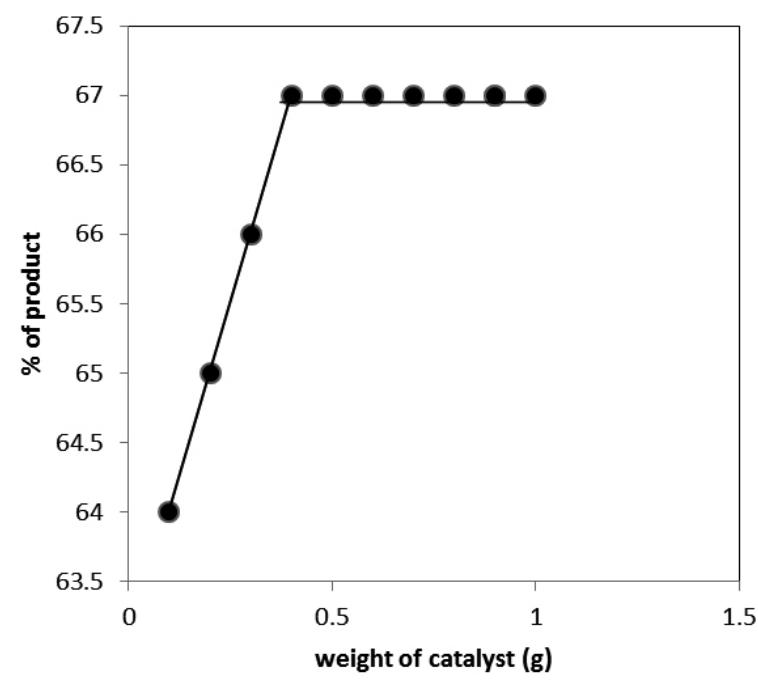

Figure 2: Effect of catalyst loading.

Table 1. Analytical and mass spectral data of chalcones synthesized by preheated fly-ash catalyzed aryl methyl ketones and substituted benzaldehydes reaction of the type $\mathrm{Ar}-\mathrm{CO}-\mathrm{CH}_{3}+\mathrm{Ar}^{\prime}-\mathrm{CHO} \rightarrow \mathrm{Ar}-\mathrm{CO}-\mathrm{CH}=\mathrm{CH}-\mathrm{Ar}^{\prime}$ under microwave irradiation.

\begin{tabular}{|c|c|c|c|c|c|c|c|}
\hline Entry & $\mathrm{Ar}$ & $A r^{\prime}$ & Product & M.W. & $\begin{array}{l}\text { Yield } \\
(\%)\end{array}$ & $\begin{array}{l}\text { M.p. } \\
\left({ }^{\circ} \mathrm{C}\right)\end{array}$ & Mass (m/z) \\
\hline 1 & $\mathrm{C}_{6} \mathrm{H}_{5}$ & $\mathrm{C}_{6} \mathrm{H}_{5}$ & $\mathrm{C}_{6} \mathrm{H}_{5} \mathrm{COCH}=\mathrm{CHC}_{6} \mathrm{H}_{5}$ & 208 & 65 & $\begin{array}{l}55-56 \\
(55-58)^{1}\end{array}$ & --- \\
\hline 2 & $4-\mathrm{N}\left(\mathrm{CH}_{3}\right)_{2} \mathrm{C}_{6} \mathrm{H}_{4}$ & $\mathrm{C}_{6} \mathrm{H}_{5}$ & $4-\mathrm{N}\left(\mathrm{CH}_{3}\right)_{2} \mathrm{C}_{6} \mathrm{H}_{4} \mathrm{COCH}=\mathrm{CHC}_{6} \mathrm{H}_{5}$ & 294 & 64 & $\begin{array}{l}87-88 \\
(87-88)^{1}\end{array}$ & --- \\
\hline 3 & $\mathrm{C}_{6} \mathrm{H}_{5}$ & $\mathrm{C}_{10} \mathrm{H}_{7}(1-\mathrm{Naph})$ & $\mathrm{C}_{6} \mathrm{H}_{5} \mathrm{COCH}=\mathrm{CHC}_{10} \mathrm{H}_{7}$ & 273 & 65 & $\begin{array}{l}104-105 \\
(104-105)^{1}\end{array}$ & --- \\
\hline 4 & $\mathrm{C}_{6} \mathrm{H}_{5}$ & $\mathrm{C}_{8} \mathrm{H}_{6} \mathrm{~N}$ (3-Indole) & $\mathrm{C}_{6} \mathrm{H}_{5} \mathrm{COCH}=\mathrm{CHC}_{8} \mathrm{H}_{6} \mathrm{~N}$ & 262 & 62 & $\begin{array}{l}140-141 \\
(140)^{1}\end{array}$ & --- \\
\hline 5 & $\mathrm{C}_{6} \mathrm{H}_{5}$ & $4-\mathrm{OHC}_{6} \mathrm{H}_{4}$ & $\mathrm{C}_{6} \mathrm{H}_{5} \mathrm{COCH}=\mathrm{CHC}_{6} \mathrm{H}_{4} \mathrm{OH}$ & 291 & 64 & $\begin{array}{l}122-123 \\
(122)^{1}\end{array}$ & --- \\
\hline 6 & $\mathrm{C}_{6} \mathrm{H}_{5}$ & $4-\mathrm{OCH}_{3} \mathrm{C}_{6} \mathrm{H}_{4}$ & $\mathrm{C}_{6} \mathrm{H}_{5} \mathrm{COCH}=\mathrm{CHC}_{6} \mathrm{H}_{4} \mathrm{OCH}_{3}$ & 291 & 64 & $\begin{array}{l}164-165 \\
(164)^{1}\end{array}$ & --- \\
\hline 7 & $4-\mathrm{NH}_{2} \mathrm{C}_{6} \mathrm{H}_{5}$ & $\mathrm{C}_{4} \mathrm{H}_{3} \mathrm{O}(3$-Furyl $)$ & $\mathrm{C}_{6} \mathrm{H}_{5} \mathrm{COCH}=\mathrm{CHC}_{4} \mathrm{H}_{3}$ & 213 & 62 & $\begin{array}{l}120-121 \\
(119-120)^{1}\end{array}$ & --- \\
\hline
\end{tabular}




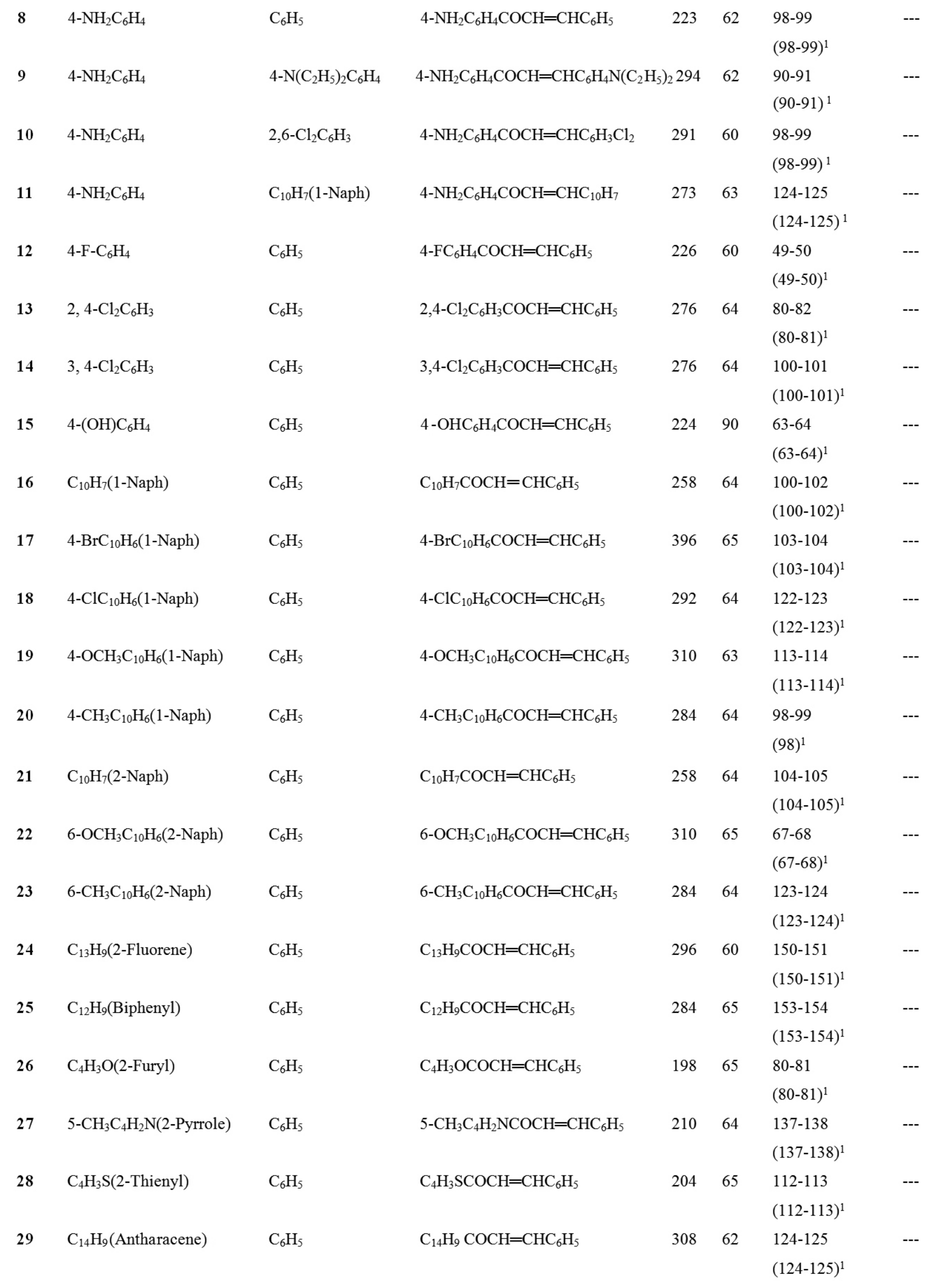




\begin{tabular}{|c|c|c|c|c|c|c|c|}
\hline 30 & 5- $\mathrm{BrC}_{4} \mathrm{H}_{2} \mathrm{~S}(2-$-Thienyl $)$ & $\mathrm{C}_{6} \mathrm{H}_{5}$ & $5-\mathrm{BrC}_{4} \mathrm{H}_{2} \mathrm{SCOCH}=\mathrm{CHC}_{6} \mathrm{H}_{5}$ & 292 & 66 & $\begin{array}{l}107-110 \\
(107-108)^{1}\end{array}$ & --- \\
\hline 31 & 5- $\mathrm{BrC}_{4} \mathrm{H}_{2} \mathrm{~S}(2$-Thienyl) & $4-\mathrm{BrC}_{6} \mathrm{H}_{4}$ & $5-\mathrm{BrC}_{4} \mathrm{H}_{2} \mathrm{SCOCH}=\mathrm{CHC}_{6} \mathrm{H}_{4} \mathrm{Br}$ & 371 & 64 & $\begin{array}{l}173-174 \\
(173-174)^{1}\end{array}$ & --- \\
\hline 32 & $\mathrm{C}_{4} \mathrm{H}_{3} \mathrm{~S}$ (3-Thienyl) & $\mathrm{C}_{6} \mathrm{H}_{5}$ & $\mathrm{C}_{4} \mathrm{H}_{3} \mathrm{SCOCH}=\mathrm{CHC}_{6} \mathrm{H}_{5}$ & 214 & 67 & $\begin{array}{l}107-108 \\
(105-106)^{30}\end{array}$ & $\begin{array}{l}214\left[\mathrm{M}^{+}\right], 137 \\
123,111,103 \\
90,77\end{array}$ \\
\hline 33 & $\mathrm{C}_{4} \mathrm{H}_{3} \mathrm{~S}$ (3-Thienyl) & $3-\mathrm{BrC}_{6} \mathrm{H}_{4}$ & $\mathrm{C}_{4} \mathrm{H}_{3} \mathrm{SCOCH}=\mathrm{CHC}_{6} \mathrm{H}_{4} \mathrm{Br}$ & 291 & 65 & $\begin{array}{l}93-94 \\
(91-92)^{30}\end{array}$ & $\begin{array}{l}291\left[\mathrm{M}^{+}\right] \\
294\left[\mathrm{M}^{2+}\right], 213, \\
181,167,155, \\
137,123,111,77\end{array}$ \\
\hline 34 & $\mathrm{C}_{4} \mathrm{H}_{3} \mathrm{~S}$ (3-Thienyl) & $4-\mathrm{BrC}_{6} \mathrm{H}_{4}$ & $\mathrm{C}_{4} \mathrm{H}_{3} \mathrm{SCOCH}=\mathrm{CHC}_{6} \mathrm{H}_{4} \mathrm{Br}$ & 291 & 66 & $\begin{array}{l}130-131 \\
(132-133)^{30}\end{array}$ & $\begin{array}{l}291\left[\mathrm{M}^{+}\right], \\
293\left[\mathrm{M}^{2+}\right], 213, \\
181,167,155, \\
137,111,77\end{array}$ \\
\hline 35 & $\mathrm{C}_{4} \mathrm{H}_{3} \mathrm{~S}$ (3-Thienyl) & $4-\mathrm{ClC}_{6} \mathrm{H}_{4}$ & $\mathrm{C}_{4} \mathrm{H}_{3} \mathrm{SCOCH}=\mathrm{CHC}_{6} \mathrm{H}_{4} \mathrm{Cl}$ & 248 & 66 & $\begin{array}{l}124-125 \\
(124-125)^{30}\end{array}$ & $\begin{array}{l}248\left[\mathrm{M}^{+}\right], \\
\left.250] \mathrm{M}^{2+}\right], 213, \\
137,124,123 \\
111,77\end{array}$ \\
\hline 36 & $\mathrm{C}_{4} \mathrm{H}_{3} \mathrm{~S}$ (3-Thienyl) & $4-\mathrm{FC}_{6} \mathrm{H}_{4}$ & $\mathrm{C}_{4} \mathrm{H}_{3} \mathrm{SCOCH}=\mathrm{CHC}_{6} \mathrm{H}_{4} \mathrm{~F}$ & 231 & 65 & $76-77$ & $\begin{array}{l}232\left[\mathrm{M}^{+}\right], \\
232\left[\mathrm{M}^{2+}\right], 234, \\
136,111,108,95 \\
77\end{array}$ \\
\hline 37 & $\mathrm{C}_{4} \mathrm{H}_{3} \mathrm{~S}$ (3-Thienyl) & $2-\mathrm{OCH}_{3} \mathrm{C}_{6} \mathrm{H}_{4}$ & $\mathrm{C}_{4} \mathrm{H}_{3} \mathrm{SCOCH}=\mathrm{CHC}_{6} \mathrm{H}_{4} \mathrm{OCH}_{3}$ & 244 & 66 & $\begin{array}{l}71-72 \\
(69-70)^{30}\end{array}$ & $\begin{array}{l}244\left[\mathrm{M}^{+}\right], 213 \\
136,123,115 \\
111,104,91,77\end{array}$ \\
\hline 38 & $\mathrm{C}_{4} \mathrm{H}_{3} \mathrm{~S}(3$-Thienyl) & $4-\mathrm{CH}_{3} \mathrm{C}_{6} \mathrm{H}_{4}$ & $\mathrm{C}_{4} \mathrm{H}_{3} \mathrm{SCOCH}=\mathrm{CHC}_{6} \mathrm{H}_{4} \mathrm{CH}_{3}$ & 228 & 65 & $\begin{array}{l}119-120 \\
(118-119)^{30}\end{array}$ & $\begin{array}{l}228\left[\mathrm{M}^{+}\right], 213 \\
136,123,115 \\
111,104,91,77\end{array}$ \\
\hline 39 & $\mathrm{C}_{4} \mathrm{H}_{3} \mathrm{~S}$ (3-Thienyl) & $3-\mathrm{NO}_{2} \mathrm{C}_{6} \mathrm{H}_{4}$ & $\mathrm{C}_{4} \mathrm{H}_{3} \mathrm{SCOCH}=\mathrm{CHC}_{6} \mathrm{H}_{4} \mathrm{NO}_{2}$ & 259 & 65 & $144-145$ & $\begin{array}{l}259\left[\mathrm{M}^{+}\right], 212, \\
148,137,135 \\
123,122,111,77\end{array}$ \\
\hline 40 & $\mathrm{C}_{4} \mathrm{H}_{3} \mathrm{~S}$ (3-Thienyl) & $4-\mathrm{NO}_{2} \mathrm{C}_{6} \mathrm{H}_{4}$ & $\mathrm{C}_{4} \mathrm{H}_{3} \mathrm{SCOCH}=\mathrm{CHC}_{6} \mathrm{H}_{4} \mathrm{NO}_{2}$ & 259 & 65 & $133-134$ & $\begin{array}{l}259\left[\mathrm{M}^{+}\right], 212, \\
148,137,135 \\
123,122,111 \\
91,77\end{array}$ \\
\hline
\end{tabular}


Table 2. Uv-Visible absorption $(\lambda \max , \mathrm{nm})$ and infrared spectral data $\left(v, \mathrm{~cm}^{-1}\right)$ of substituted styryl 3-thienyl ketones(entries 32-40).

\begin{tabular}{|c|c|c|c|c|c|c|c|c|}
\hline Entry & $\mathrm{X}$ & $\lambda \max$ & $\mathrm{CO}_{(s-i s)}$ & $\mathrm{CO}$ (s-trans) & $\mathrm{CH}_{i p}$ & $\mathrm{CH}_{o p}$ & $\mathrm{CH} \mathrm{CH}_{o p}$ & $\mathrm{C}=\mathrm{C}_{o p}$ \\
\hline 32 & $\mathrm{H}$ & 310.40 & 1653.00 & 1598.00 & 1154.00 & 762.00 & 1073.00 & 564.00 \\
\hline 33 & $3-\mathrm{Br}$ & 315.20 & 1658.00 & 1599.00 & 1179.00 & 782.00 & 1071.00 & 575.00 \\
\hline 34 & $4-\mathrm{Br}$ & 314.40 & 1654.00 & 1596.00 & 1176.00 & 753.00 & 1068.00 & 570.00 \\
\hline 35 & $4-\mathrm{Cl}$ & 315.20 & 1651.00 & 1596.00 & 1176.00 & 759.00 & 1068.00 & 571.00 \\
\hline 36 & $4-\mathrm{F}$ & 310.60 & 1655.00 & 1599.00 & 1173.00 & 729.00 & 1073.00 & 570.00 \\
\hline 37 & $2-\mathrm{OCH}_{3}$ & 339.70 & 1652.70 & 1589.06 & 1191.79 & 767.53 & 1072.23 & 595.89 \\
\hline 38 & $4-\mathrm{CH}_{3}$ & 322.40 & 1650.77 & 1589.06 & 1180.22 & 798.38 & 1076.08 & 574.68 \\
\hline 39 & $3-\mathrm{NO}_{2}$ & 327.80 & 1654.62 & 1571.70 & 1195.65 & 742.46 & 1081.87 & 576.61 \\
\hline 40 & $4-\mathrm{NO}_{2}$ & 317.60 & 1656.55 & 1592.91 & 1172.51 & 752.10 & 1068.37 & 574.68 \\
\hline
\end{tabular}

Table 3. The ${ }^{1} \mathrm{H}$ and ${ }^{13} \mathrm{C}$ NMR spectral data $(\delta$, ppm) of substituted styryl 3-thienyl ketones(entries 32-40)

\begin{tabular}{lllllll}
\hline Entry & $\mathrm{X}$ & Vinyl $\mathrm{H}_{\alpha}$ & Vinyl $\mathrm{H}_{\beta}$ & $\mathrm{CO}$ & $\mathrm{C}_{\alpha}$ & $\mathrm{C}_{\beta}$ \\
\hline $\mathbf{3 2}$ & $\mathrm{H}$ & 7.399 & 7.816 & 183.94 & 122.74 & 144.08 \\
$\mathbf{3 3}$ & $3-\mathrm{Br}$ & 7.394 & 7.768 & 183.50 & 123.11 & 142.88 \\
$\mathbf{3 4}$ & $4-\mathrm{Br}$ & 7.393 & 7.749 & 183.67 & 123.21 & 142.96 \\
$\mathbf{3 5}$ & $4-\mathrm{Cl}$ & 7.389 & 7.763 & 183.68 & 123.12 & 142.97 \\
$\mathbf{3 6}$ & $4-\mathrm{F}$ & 7.337 & 7.786 & 183.77 & 122.42 & 143.04 \\
$\mathbf{3 7}$ & $2-\mathrm{CH}_{3}$ & 7.332 & 8.121 & 183.99 & 123.84 & 143.17 \\
$\mathbf{3 8}$ & $4-\mathrm{CH}_{3}$ & 7.371 & 7.806 & 184.12 & 121.73 & 144.25 \\
$\mathbf{3 9}$ & $3-\mathrm{NO}_{2}$ & 7.525 & 7.846 & 183.07 & 122.27 & 141.03 \\
$\mathbf{4 0}$ & $4-\mathrm{NO}_{2}$ & 7.511 & 7.827 & 183.03 & 124.26 & 142.62 \\
\hline
\end{tabular}

\section{Microbial activities}

Chalcones possess a wide range of biological activities such as antibacterial $^{32}$, antifungal ${ }^{32}$, antiviral ${ }^{33}$, antifeedant ${ }^{3,}, 29$, anticancer ${ }^{34}$ antimalarial ${ }^{35}$, antituberclosis ${ }^{28}$, antiAIDS ${ }^{36}$ and antioxidant ${ }^{37}$ activities. These multipronged activities present in different chalcones are examined against respective microbes-bacteria's and fungi.

\section{Antibacterial sensitivity assay}

Antibacterial sensitivity assay was performed using Kirby-Bauer ${ }^{38}$ disc diffusion technique. In each Petri plate about $0.5 \mathrm{ml}$ of the test bacterial sample was spread uniformly over the solidified Mueller Hinton agar using sterile glass spreader. Then the discs with $5 \mathrm{~mm}$ diameter made up of Whatmann No.1 filter paper, impregnated with the solution of the compound were placed on the medium using sterile forceps. The plates were incubated for 24 hours at $37^{\circ} \mathrm{C}$ by keeping the plates upside down to prevent the collection of water droplets over the medium. After 24 hours, the plates were visually examined and the diameter values of the zone of inhibition were measured. Triplicate results were recorded by repeating the same procedure.

The antibacterial activities of all prepared chalcones have been studied against two gram positive pathogenic strains Staphylococcus aureus, Enterococcus faecalis and four gram negavtive strains Escherichia coli, Klebsiella species, Psuedomonas and Proteus vulgaris. The disc diffusion technique was followed using the Kirby-Bauer ${ }^{38}$ method, at a concentration of $250 \mu \mathrm{g} / \mathrm{mL}$ with Ampicillin and Streptomycin used as the standard drugs. The measured antibacterial activities of all oxiranes are presented in Table 4. Compound $\mathbf{3 8}$ showed maximum zone of inhibition against Escherichia coli, with greater than $20 \mathrm{~mm}$ compared to the chalcones $\mathbf{3 4}, \mathbf{3 6}, \mathbf{3 9}$, and $\mathbf{4 0}$ and they are moderatively active in 13-19 mm of zone of inhibition. Ketone 38 was active with in $8-12 \mathrm{~mm}$ of zone of inhibition. The ketones $\mathbf{3 3}, \mathbf{3 7}$ and $\mathbf{4 0}$ were found to be effective against $S$. aureus within $20-24 \mathrm{~mm}$ of zone of inhibition. Compounds 34, 36, 38 and $\mathbf{3 9}$ are moderately active within 13-19 mm of zone of inhibition. The chalcone 35 was active within $8-12 \mathrm{~mm}$ of zone of inhibition. The chalcone derivatives $\mathbf{3 4}$ and $\mathbf{3 6}$ were more active against Pseudomonas a showing greater than $20 \mathrm{~mm}$ zone of inhibition and the other derivatives showed the zone of inhibitions between 12-19 $\mathrm{mm}$. The ketones 33, 34, $\mathbf{3 7}$ and
40 are effective against Klebsiella with $20-24 \mathrm{~mm}$ zone of inhibition while the other ketones showed a moderate activity. The chalcones $\mathbf{3 2 , 3 6}$ and $\mathbf{3 9}$ were active when it is screened against $P$. vulgaris and the other compounds are less effective. The ketones 32, 34 and $\mathbf{3 7}$ showed activities against $E$-faecalis when they are screened with $20-24 \mathrm{~mm}$ zone of inhibition.

\section{Antifungal sensitivity assay}

Antifungal sensitivity assay was performed using Kirby-Bauer ${ }^{38}$ disc diffusion technique. PDA medium was prepared and sterilized as above. It was poured (ear bearing heating condition) in the Petri-plate which was already filled with $1 \mathrm{~mL}$ of the fungal species. The plate was rotated clockwise and counter clock-wise for uniform spreading of the species. The discs were impregnated with the test solution. The test solution was prepared by dissolving $15 \mathrm{mg}$ of the chalcone in $1 \mathrm{~mL}$ of DMSO solvent. The medium was allowed to solidify and kept for 24 hours. Then the plates were visually examined and the diameter values of zone of inhibition were measured. Triplicate results were recorded by repeating the same procedure.

The study of antifungal activities of all chalcones has been done with Candida albicans as the fungal strain using the disc diffusion technique and the other two strains Penicillium species and Aspergillus niger, the dilution method was adopted. The drug dilution was kept as $50 \mu \mathrm{g} / \mathrm{mL}$. Griseofulvin has been taken as the standard drug. The observed antifungal activities of all chalcones are presented in Table 5. The study of antifungal activities of all chalcones against $C$. albicans, showed that the three compounds 34, 37 and 39 are effective with $20 \mathrm{~mm}$ as the zone of inhibition in $250 \mu \mathrm{g} / \mathrm{disc}$ while chalcones $\mathbf{3 5}, \mathbf{3 6}, \mathbf{3 8}$ and $\mathbf{4 0}$ are active with 13-19 $\mathrm{mm}$ zone of inhibition and the compound $\mathbf{3 2}$ was the least active with $8-12 \mathrm{~mm}$ zone of inhibitions. Compounds $\mathbf{3 5}$ and $\mathbf{3 9}$ are visible against Penicillum species, in the development of the fungal colony and 2-3 colonies are recorded for the compounds 33, 36 and 40 . The inhibition of ketones against A.niger was less in two compounds 34 , and 37 being highly active followed by $\mathbf{3 2}, \mathbf{3 3}, \mathbf{3 5}, 39$ and 40. Presence of a methoxy, methyl, dimethyl and bromo substituents are responsible for antimicrobial activities of chalcones. 
Table 4. Antibacterial activities of substituted styryl 3-thienyl ketones(entries 32-40).

\begin{tabular}{|c|c|c|c|c|c|c|c|}
\hline Entry & $\mathrm{X}$ & E-coli & S.aures & Pseudomonas & Klebsiella & P.vulgaris & Entrococcus faecalis \\
\hline 32 & $\mathrm{H}$ & + & -- & + & \pm & ++ & ++ \\
\hline 33 & $3-\mathrm{Br}$ & -- & ++ & + & ++ & + & \pm \\
\hline 34 & $4-\mathrm{Br}$ & + & + & ++ & ++ & + & ++ \\
\hline 35 & $4-\mathrm{Cl}$ & ++ & \pm & -- & -- & + & + \\
\hline 36 & $4-\mathrm{F}$ & + & + & ++ & + & ++ & + \\
\hline 37 & $2-\mathrm{CH}_{3}$ & -- & ++ & + & ++ & -- & ++ \\
\hline 38 & $4-\mathrm{CH}_{3}$ & \pm & + & + & -- & \pm & + \\
\hline 39 & $3-\mathrm{NO}_{2}$ & + & + & \pm & -- & ++ & \pm \\
\hline 40 & $4-\mathrm{NO}_{2}$ & + & ++ & + & ++ & + & --- \\
\hline
\end{tabular}

Disc size: $6.35 \mathrm{~mm}$; Duration: 24-45 h; Standard: Ampicillin $(30-33 \mathrm{~mm})$ and Streptomycin $(20-25 \mathrm{~mm})$; Control: Methanol; ---: No activities; \pm : Active (8-12 mm); +: Moderately active(13-19 mm); ++: Active(20-24 mm).

Table 5. Antifungal activities of substituted styryl 3-thienyl ketones(entries 32-40).

\begin{tabular}{|c|c|c|c|c|}
\hline \multirow{2}{*}{ Entry } & \multirow{2}{*}{$\mathrm{X}$} & \multirow{2}{*}{$\begin{array}{l}\text { Disc diffusion technique } \\
\qquad \begin{array}{l}(250 \mu \mathrm{g} / \mathrm{mL}) \\
\text { Candida albicans }\end{array}\end{array}$} & \multicolumn{2}{|c|}{ Drug dilution method $(50 \mu \mathrm{g} / \mathrm{mL})$} \\
\hline & & & Penicillium & Aspergillus niger \\
\hline 32 & $\mathrm{H}$ & \pm & + & + \\
\hline 33 & $3-\mathrm{Br}$ & --- & \pm & + \\
\hline 34 & $4-\mathrm{Br}$ & ++ & + & ++ \\
\hline 35 & $4-\mathrm{Cl}$ & + & ++ & + \\
\hline 36 & $4-\mathrm{F}$ & + & \pm & \pm \\
\hline 37 & $2-\mathrm{CH}_{3}$ & ++ & --- & ++ \\
\hline 38 & 4- $\mathrm{CH}_{3}$ & + & + & --- \\
\hline 39 & $3-\mathrm{NO}_{2}$ & ++ & ++ & + \\
\hline 40 & $4-\mathrm{NO}_{2}$ & + & \pm & + \\
\hline
\end{tabular}

Standard: Griseofulvin and Gentamycin; Duration : 72 h; Control: Methanol; Medium: Potato dextrose agar; ++: No fungal colony; +: One fungal colony; \pm : Two-three fungal colonies;---: Heavy fungal colony.

\section{CONCLUSION}

We have developed an efficient catalytic method for synthesis of chalcones by Crossed-Aldol reaction using a solvent free environmentally greener catalyst preheated fly-ash under microwave irradiation between aryl ketones and aldehydes. This reaction protocol offers a simple, economical, environmentally friendly, non-hazards, easier work-up procedure and good yields. The antimicrobial activities of chalcones have been studied using Bauer-Kirby method.

\section{ACKNOWLEDGEMENT}

The authors thank SAIF, IIT Chennai-600 036, for recording NMR spectra of chalcones.

\section{REFERENCES}

1. G. Thirunarayanan, P. Mayavel, K. Thirumurthy, Spectrochim. Acta. 91A, 18, (2012)

2. G. Thirunarayanan, G. Vanangamudi, V. Sathiyendiran, K. Ravi, Indian J. Chem. 50B, 593, (2011)

3. G. Thirunarayanan, J. Indian Chem. Soc. 85, 447, (2008)

4. G. Thirunarayanan, G. Vanangamudi, E. J. Chem. 4, 90, (2007)

5. G. Thirunarayanan, Indian J. Chem. 46B, 1511, (2007)

6. S. Kobayashi, H. Kiyohara, M. J. Yamaguchi, J. Am. Chem. Soc. 708, 133, (2011)

7. W. Li, W. Wu, J. Yang, X. Liang Y. Ye, Synthesis. 1085, (2011)

8. S. H. Leung, S. A. Angel, J. Chem. Edn. 81, 1492, (2004)

9. G. Thirunarayanan, J. Korean Chem. Soc. 52, 369, (2008)

10. G. Thirunarayanan, G. Vanangamudi, Arkivoc. 58, 12, (2006) 
11. P. Salehi, M. Dabiri, M. A. Zolfigol, M. A. B. Fard, J. Braz. Chem. Soc. 15, 773. (2004)

12. G. Thirunarayanan, P. Ananthakrishna Nadar, J. Indian Chem. Soc. 83, 1107, (2006)

13. D. R. Palleros, J. Chem. Edn. 81, 1345, (2004)

14. S. A. Basaif, T. R. Sobahi, A. K. Khalil, M. A. Hassan, Bull. Korean Chem. Soc. 26, 1677, (2005)

15. Q. Xu, Z. Yang, D. Yin, F. Zhang, Catal. Commun. 9, 1579, (2008)

16. P. Kumar, S. Kumar, K. Husain, A. Kumar, Bioorg. Med. Chem. 18, 4965 (2011)

17. Z. Zhang, Y. W. Dong, G. W. Wang, Chem. Lett. 32, 966, (2003)

18. H. E. Blackwell, Curr. Opn. Chem. Biol. 10, 203, (2006)

19. G. Thirunarayanan, K. Thirumurthy, G. Vanangamudi, M. Subramanian, R. Arulkumaran, D. Kamalakkannan, R. Sundararajan, S. P. Sakthinathan, S. Vijayakumar, K. Ranganathan and R. Suresh, Elixir Org. Chem. $\mathbf{4 5}$, 7898, (2012)

20. B. F. G. Johnson, J. Lewis, G. R. Stephenson, E. J. S. Vichi, J. Chem. Soc. Dalton Trans. 369, (1978)

21. N. S. Fernandes, M. A. S. Carvalho, R. A. Filho, Mendes, C. B. Meliosand, M. J. Ionashiro, Thermal Anal. Cal. 76, 193, (2010)

22. Y. Xiuying, P. J. An-shun, Linyi Teachers Coll. 23, O621.3 (2004)

23. B. Krishnakumar, R. Velmurugan, M. Swaminathan, Catal. Commun. 12, $375,(2011)$

24. J. K. Rajput, G. Kaur, Tetrahedron Letters, 53, 646, (2012)

25. M. Sivakumar, S. Phrabu Sreeneivasan, V. Kumar, M. Doble, Bioorg. Med. Chem. Lett. 17, 3169 (2007)
26. X. Liu, M. L. Go, Bioorg. Med. Chem. 14, 153, (2006)

27. R. Arulkumaran, R. Sundararajan, G. Vanangamudi, M. Subramanian, K. Ravi, V. Sathiyendiran, S. Srinivasan, G. Thirunarayanan, Iup. J. Chem. 3, 82, (2010)

28. J. Deng, T. Sanchez, Q. A. M. Lalith, Bioorg. Med. Chem. 15, 4985, (2007)

29. G. Thirunarayanan, S. Surya, S. Srinivasan, G. Vanangamudi, V. Sathyendiran, Spectrochim. Acta. 75A, 152, (2010)

30. Y. Budak, M. Burcu Gürdere, M. Keçeci, M. Ceylan, Bull. Chem. Soc. Ethiop. 85, 24, (2010)

31. K. Ranganathan, R. Arulkumaran, D. Kamalakkannan, G. Vanangamudi, G. Thirunarayanan, Iup J. Chem. 4, 60, (2011)

32. K. Lahtchev, D. I. Batovska, P. V. Parushev St, M. Ubiyvock, A. Sibirny, A. Eur. J. Med. Chem. 43, 2220, (2008)

33. I. El-Subbagh Hussein, S. M. Abu-Zaid, M. A. Mahran, A. Badria Farid, A. M. Al-Obaid, J. Med. Chem. 43, 2915, (2000)

34. A. Modzelewska, C. Pettit, G. Achanta, N. E. Davidson, P. Huang, S. R. Khan, Bioorg. Med. Chem. 14, 3491, (2006)

35. J. N. Dominguez, C. Leon, J. Rodrigues, IL Farmaco, 60, 307, (2005)

36. Y. M. Lin, Y. Zhon, M. T. Flavin, L. M. Zhon, W. Ne, F. C. Chen, Bioorg. Med. Chem. 10, 2795, (2002)

37. M. W. Weber, L. A. Hunsaker, S. F. Abcouwer, L. M. Decker, D. Vander Jagat, Bioorg. Med. Chem. 13, 3811, (2005)

38. A. W. Bauer, W. M. Kirby, J. C. Sherris, M. Truck, Am. J. Clin. Pathol. 45, 493, (1966) 